\title{
39. BIOSTRATIGRAPHIC SUMMARY OF LEG 32
}

\author{
H. Luterbacher, ${ }^{1}$ M. Caron, ${ }^{2}$ R.L. Fleisher,${ }^{3}$ H.P. Foreman, ${ }^{4}$ M. Toumarkine, ${ }^{5}$ and E. Vincent ${ }^{6}$
}

\section{INTRODUCTION}

All cores recovered during Leg 32 were investigated for calcareous nannoplankton, silicoflagellates, Radiolaria, and foraminifera. The occurrence of the various groups of microfossils at the 10 sites is indicated on Figure 1 .

In addition to the work done by the shipboard scientists, other specialists have been asked to investigate specific groups of microfossils (R.L. Fleisher: Oligocene planktonic foraminifera; $M$. Toumarkine: late and middle Eocene planktonic foraminifera; M. Caron: Late Cretaceous planktonic foraminifera; A.H. Cheetham: bryozoans from Site 308; J. Ferrer: benthonic foraminifera from Site 308; L. Hottinger: larger foraminifera from Site 309; R. Lehmann: crustacean coproliths from Site 304). A shore-lab investigation of late Cretaceous planktonic foraminifera was carried out by J.F. Longoria.

A considerable number of samples were processed for palynomorphs, (by Y. Caro: Cenozoic; M. Millioud: Cretaceous), but the results were very disappointing.

A few groups of microfossils, ostracodes, Cenozoic and Late Cretaceous smaller benthonic foraminifera (except Site 308), fish debris, and coral fragments (Sites $308,309)$ have not yet been studied.

Recovery was very poor in the older parts of the cored sections. In many cores, only chert chips and cuttings of doubtful origin, or traces of sediment in insufficient quantities, could be obtained. This generally rather poor recovery affected the results of the biostratigraphic studies mainly in the Cretaceous intervals and also in parts of the Paleogene.

Several sites are located in deep to very deep water $(>4500 \mathrm{~m})$. Therefore, calcareous microfossils are present only in the oldest parts of the sections.

The sites drilled in the northwestern Pacific during Leg 32 can be subdivided into three groups:

1) Sites drilled on Shatsky Rise (Sites 305, 306) and Hess Rise (Site 310), which were intended to furnish biostratigraphic reference sections;

2) Sites drilled in the deep-sea floor (depths exceeding $5500 \mathrm{~m}$ ), with the main objective to date Mesozoic magnetic anomalies of the Japanese and Hawaiian sets of lineations (Sites 303, 304, and 307); and

\footnotetext{
'Esso Production Research-European, Bègles, France.

${ }^{2}$ University of Fribourg, Fribourg, Switzerland.

${ }^{3}$ Exxon Production Research Co., Houston, Texas.

${ }^{\circ}$ Oberlin College, Oberlin, Ohio.

'Swiss Federal Institute of Technology, Zurich, Switzerland.

'Scripps Institution of Oceanography, La Jolla, California.
}

3) Sites located on Koko Seamount (Sites 308, 309), and the northeastern Mid-Pacific Mountains (Site 313), which were drilled to improve the knowledge of the development of these features. Although Site 311 was primarily intended to date the young end of the Hawaiian lineations, its main worth turned out to be its dating of Hawaiian Ridge volcanism.

\section{SHATSKY RISE (SITES 305, 306) AND HESS RISE (SITE 310)}

On both rises, relatively complete sequences of Quaternary to late or middle Miocene sediments were recovered. Calcareous nannoplankton, silicoflagellates, and Radiolaria are in general well preserved, whereas planktonic foraminifera are affected by dissolution.

At Sites 305 and 310, part of the middle Miocene and most of the early Miocene are missing. On Hess Rise, this hiatus includes also the late Oligocene.

The Paleogene is rich in intervals with strong dissolution affecting mainly the planktonic foraminifera.

The Cretaceous-Tertiary boundary is marked by a hiatus, which corresponds to the early Paleocene at Site 305 (Shatsky Rise) and to the entire Paleocene and Maestrichtian (only late Maestrichtian according to coccoliths) at Site 310 (Hess Rise).

On Hess Rise, the Cretaceous cored at Site 310 includes Campanian (early Maestrichtian according to coccoliths) to Cenomanian sediments. Foraminifera are often dissolved in part. Radiolaria are present in the Santonian to Cenomanian interval.

On the Shatsky Rise, Maestrichtian to Coniacian deposits can be zoned without major discrepancies by coccoliths and planktonic foraminifera. In general, the preservation of the calcareous microfossils is good, although a few intervals show effects of dissolution. No Turonian to late Cenomanian foraminiferal faunas were found.

Planktonic foraminifera are present down to the Aptian (Site 305, Albian at Site 306). In the older cores, only benthonic foraminifera were found. Their occurrence is very patchy and their preservation is often very poor. Age determinations, based on foraminifera, below the Aptian are tentative; therefore ages are mainly based on coccoliths which are present in sufficient number and in a good preservation state in almost all cores. The coccoliths date the oldest sediments recovered at Site $\mathbf{3 0 6}$ as early Berriasian.

Radiolaria occur in variable number and in a good state of preservation throughout the Cretaceous (Shatsky Rise-Early Cretaceous; Hess Rise-Late Cretaceous). A zonation based on the Radiolaria of the Early and part of the Late Cretaceous was established and compared to the ages of the same samples based on coccoliths and foraminifera. This zonation is discussed in detail by Foreman (this volume). 


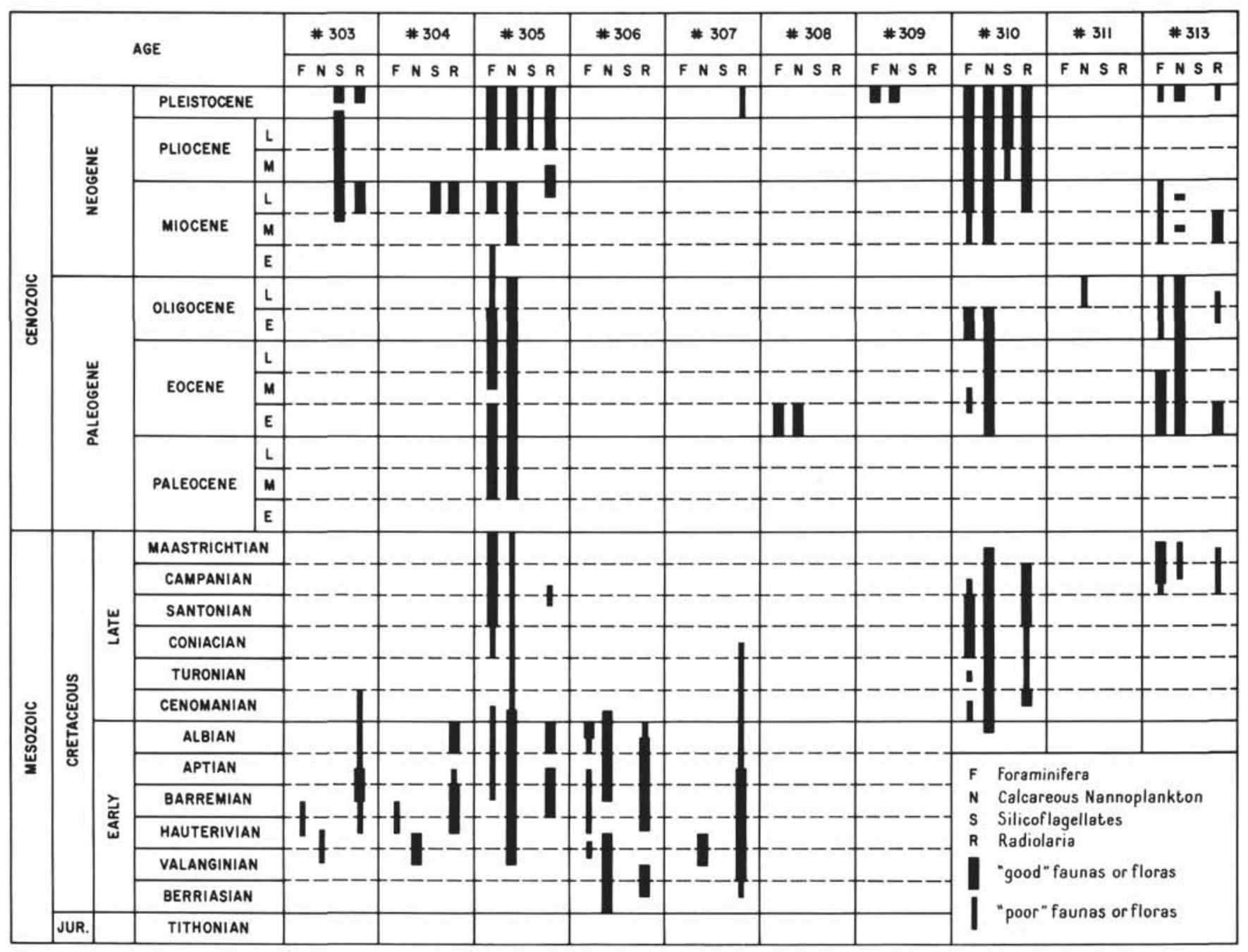

Figure 1. Stratigraphic distribution of microfossils in sites drilled during Leg 32.

Figure 2 gives a correlation of first and last occurrences of stratigraphically useful Radiolaria and foraminifera in the Cretaceous of Shatsky Rise and Hess Rise. Figure 3 shows the radiolarian zones compared to the ages attributed to the same intervals based on coccoliths and foraminifera. Ages based on coccoliths and foraminifera correspond reasonably well in the Maestrichtian to Aptian interval, but below this stage coccoliths consistently indicate a considerably older age than the foraminifera (cf. Sites 305, 306, and also Sites $303,304)$.

\section{DEEP-WATER SITES LOCATED ON MESOZOIC MAGNETIC ANOMALIES} (SITES 303, 304, 307, 311)

At Sites 303, 304, and 307, a majority of the cores contains only siliceous microfossils. In the Neogene, age determinations are based on silicoflagellates and Radiolaria, whereas large parts of the Cretaceous are dated by Radiolaria only. Age assignments of the Cretaceous Radiolarian zones are based on their correlation with coccoliths and foraminifera at Sites 305,306 , and 310 (see above). Calcareous microfossils occur only in the cores immediately overlying the basalt (only coccoliths at Site 307). A noteworthy curiosity is the presence of crustacean coproliths in a calcite vein of the basalt at Site 304, (see Lehmann, this volume).

At Sites 303 and 304, only Quaternary to late Miocene (Site 304) or late middle Miocene (Site 303) sediments were found. The entire Paleogene and most of the Late Cretaceous are not represented. At Site 307, Core 1 contains Quaternary Radiolaria, whereas Core 2, which was cut only 30 meters deeper, is dated as early Late Cretaceous to Albian by a radiolarian faunule. Because of discontinuous coring, the nature of this regional hiatus could not be established.

The age of the sediments overlying the magnetic anomalies M-4 (Site 303) and M-9 (304) are determined to be Hauterivian to Valanginian based on coccoliths, or Barremian to Hauterivian based on foraminifera. The basal sediments above M-21 (Site 307) are assigned an age of early Hauterivian to late Valanginian (coccoliths) or Valanginian to Berriasian (Radiolaria).

\section{SITES ON KOKO GUYOT (SITES 308, 309) AND THE NORTHEASTERN MID-PACIFIC MOUNTAINS (SITE 313)}

The 7.3 meters of sediments recovered from Site 308 contain a homogeneous early Eocene microfauna indicating deposition at a sublittoral depth of probably less 


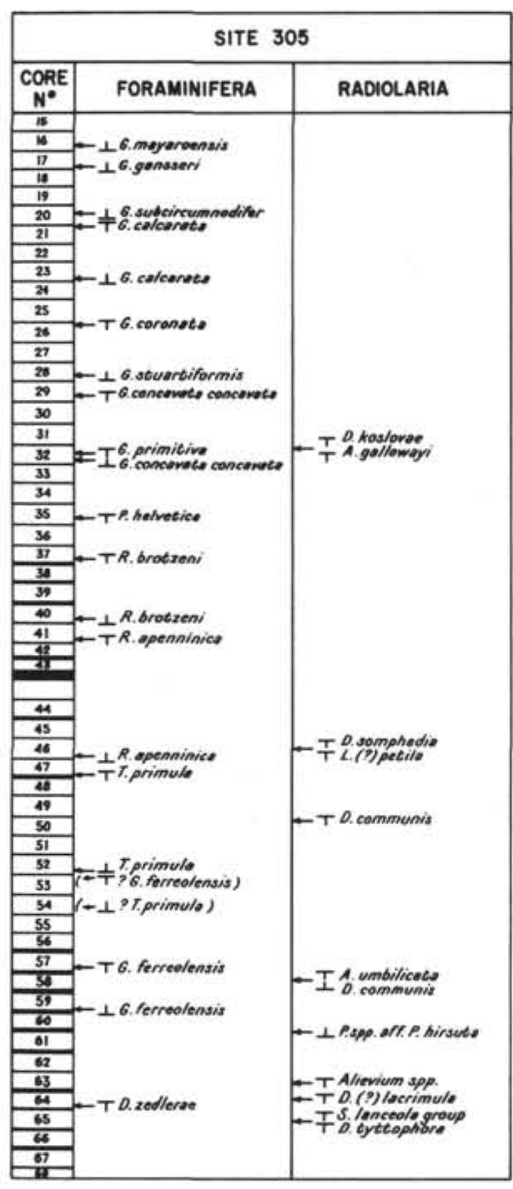

T Youngest, occurence $\perp$ Oldest occurence
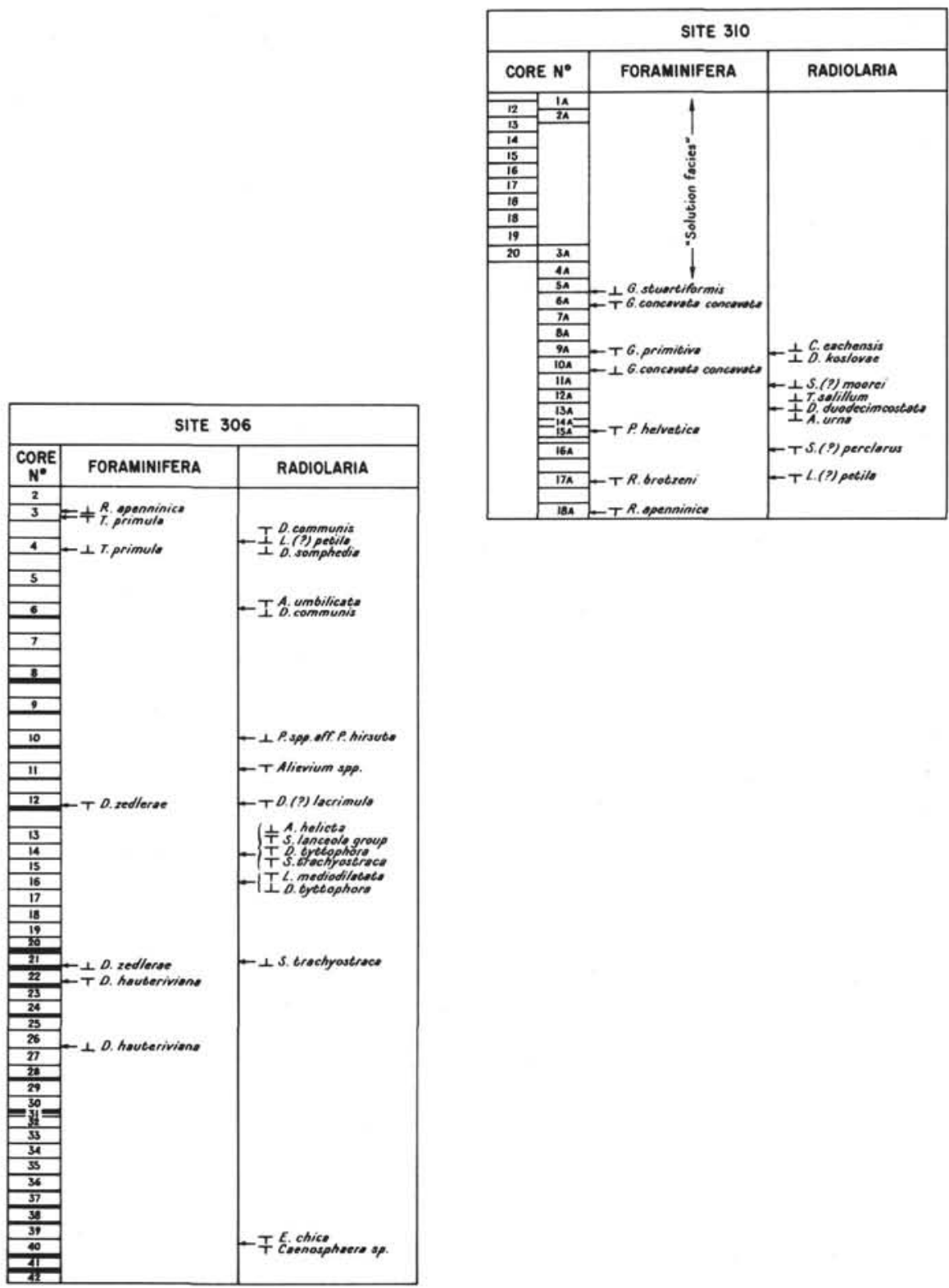

Figure 2. Correlation of foraminiferal and radiolarian events in the Cretaceous of the Shatsky Rise (Sites 305, 306) and the Hess Rise (Sites 310, 310A).

than 60 meters. The small amount of cuttings from Site 309 consists of a mixture of Quaternary microfossils and late Oligocene to early Miocene larger foraminifera associated with reef debris. No Radiolaria were recovered from either of these sites.

Only 19 meters of sediment were recovered during the aborted attempt to date $\mathrm{M}-2$ of the Hawaiian lineations (Site 311). They can be dated as late Oligocene by coccoliths, but contain no Radiolaria and foraminifera.

Site 313 was drilled in a sediment-filled basin of the northeastern Mid-Pacific Mountains. The Quaternary to late Eocene and the Maestrichtian intervals were not cored continuously. Coccoliths and planktonic foraminifera occur in variable amounts and variable preservation states in all cores. Radiolaria are restricted to the Quaternary to middle Miocene, the early Eocene and the Late Cretaceous. The influx of volcanic clastics coincides approximately with the top of the Campanian, and the oldest sediments recovered are of early Campanian age. 

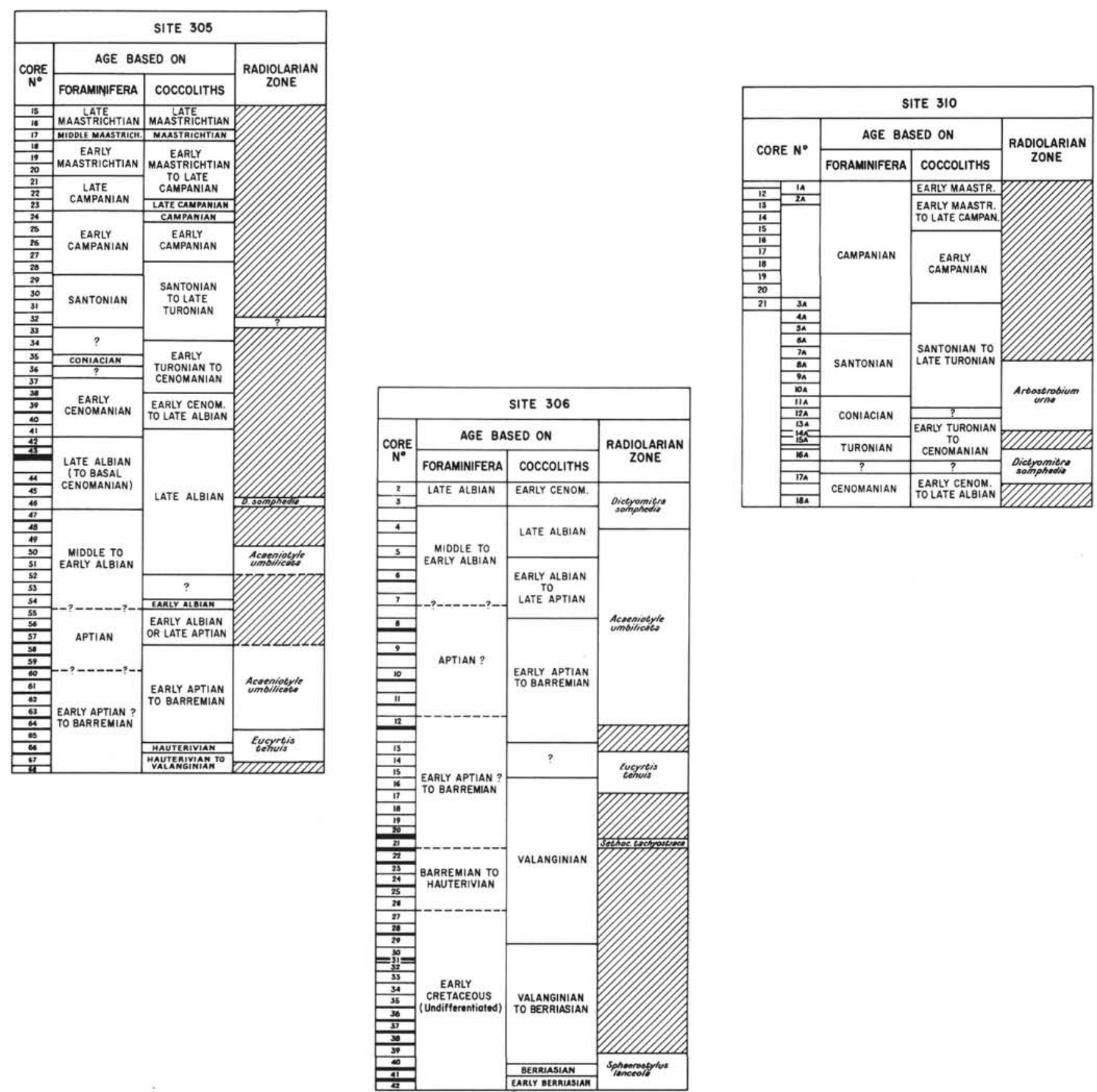

Figure 3. Correlation of radiolarian zones with ages based on foraminifera and coccoliths in the Cretaceous of Sites 305, 306 , and 310 . 